\title{
RECONSTRUCTION OF ADMINISTRATIVE BUILDINGS OF THE 70'S: THE POSSIBILITY OF ENERGY MODERNIZATION
}

Darya Nemova*

Institute of Civil Engineering,Saint-Petersburg State Polytechnical University, Saint-Petersburg, Russia Vera Murgul

Institute of Civil Engineering,Saint-Petersburg State Polytechnical University, Saint-Petersburg, Russia Viktor Pukhkal

Faculty of Engineering Ecology and Municipal Facilities, St. Petersburg State University of Architecture and Civil Engineering, St. Petersburg, Russia

Alex Golik

Institute of Civil Engineering,Saint-Petersburg State Polytechnical University, Saint-Petersburg, Russia Eugene Chizhov

Institute of Civil Engineering,Saint-Petersburg State Polytechnical University, Saint-Petersburg, Russia

Nikolay Vatin

Institute of Civil Engineering,Saint-Petersburg State Polytechnical University, Saint-Petersburg, Russia

The question of energy efficiency and energy saving has high degree of relevance. It was revealed that in the view of considerable heat consumption the administrative buildings that had been constructed in Russia before 1996 require modernization. Built at their time and based on the actual at that moment standards of the thermal protection, nowadays these buildings became automatically unsatisfactory from this viewpoint. At the same time their operating period is not finished, which means that those buildings do not need a major overhaul. The paper presents an algorithm for upgrade of the thermo-technical parameters of the framing as well as the parameters of overall energy consumption to the modern requirements without complex reconstruction of the building or ceasing their normal functioning. The building selected for examination is the "Uchebny corpus" of St-Petersburg Polytechnic University. This administrative building is typical from both: construction and exploitation. That is why the conclusions made in this research can be applicable to most of framed administrative buildings of the above period.

Key words: Energy efficiency, Energy saving, Insulation Coating, Heat conductivity, Payback period

\section{INTRODUCTION}

On power consumption of buildings the considerable part of developed thermal energy leaves. One of the main objectives of designers consists in improvement of quality of planning, architectural and construction concepts, depreciation of construction and power consumption of buildings and constructions, reduction of specific capital investments on unit of the put into operation power. Over a significant period the requirements of technical standards for thermal insulation in Russia were quite low [14]. For this reason currently the administrative buildings constructed before 1996 require a full-scale reconstruction of the building envelopes and modernization of the systems of technical equipment (central-heating and ventilation systems) with the purpose of increasing the efficiency of energy consumption [23].

The necessity of the reconstruction is closely related to the approvement of the federal law № 261 "On Energy-saving, Energy Efficiency and Changes to the Legislation of the Russian Federation" dated November 23, 2009 [06]. The regulations imposed by this law are similar to the directive [01]. The problems of energy-saving that are being solved by the European states are analogous to the problem considered in this article [03].

After 2000 with the changes in the Building Code II-3-79 ("Thermal engineering") [19] and with the 
approvement of its updated version dated 2012 the requirements for the thermal resistance of building envelopes have increased by factor 2.5 [07]. Therefore, all the buildings that were constructed before the legislative changes are obsolete [08]. At the same time their operating period is not finished, which means that those buildings do not need a major overhaul [16].

In this paper outlined the possible ways of reducing the energy consumption of "Gidrokorpus 2" of Saint Petersburg State Polytechnical University (Politekhnicheskaya Street, 29, Saint Petersburg).

A number of research works is dedicated to decrease of thermal losses in existing buildings reconstruction. The actions directed on reduction of losses of heat and increase of level of ther mal protection of external protecting designs demand an integrated approach. The replacement of technical equipment and the renovation of the building envelope are considered as the major measures to increase energy-saving $[04,09,13,18]$.

One of the key problems that hamper the development of energy-efficient technologies is the absence of the universal methodological approach to complex evaluation of economic efficiency of energy-saving technologies [02]. In many cases this is a reason for misleading conclusions that might cause mistakes in making financial decisions.

\section{THE GOAL AND OBJECTIVES OF THE RESEARCH}

The goal of the research is to elaborate a system of measures that allow to improve the thermotechnical characteristics of the building envelope and energy consumption of the building in the way that they comply with the modern standards and make it possible to avoid a major overhaul and an undesirable interruption in functioning of the building.

Considering the fact that there is a significant number of administrative buildings constructed in accordance with the obsolete frame models (during the indicated period), and in the view of the growing need for their reconstruction, it is clear that the development of a system of measures is an important and scientifically relevant objective [14].

To define the basic measures it is necessary to consider the exact technical state of the building and its current energy consumption [15].
The thermal resistance of all framing constructions can be obtained basing on the thermo-technical theoretical calculations. However, taking into account the long period of the preliminary exploitation of these buildings it is highly desirable to perform a number of measurements. Hence, the below steps follow from the goal specified:

- performing of the complex examination of the typical building,

- based on that examination propose a list of transformations to avoid the complete overhaul,

- find the optimal thermal isolation of the outer walls of the above type of buildings [18].

\section{LITERATURE REVIEW}

Significant contribution to the solution of theoretical and practical issues of energy efficiency and walling made the following scientists: Gorshkov A., Gagarin V.G., Trutneva M.S., Samarin O.D., Butovsky I.N., M.N. Efymenko.,Tabunschikov Y. A, Bohuslav L.D V.K. Savin, Yezerskiy V.A., Monastyrev P.V., Klychnikov R.Y. and many others $[02,05,13,17,18,19]$.

Measures aimed at reducing of heat loss and increasing heat protection of external walling always demanded economic justification. Payback period of such events investigated Boguslavskiy L.D., Gagarin VG Samarin OD etc.

Boguslavskiy L.D. proposed a model that allows assessment of "economic utility", "optimal" walling thermal resistance [02].

Savin V.K. created thermogram of energy consumption dependence on the creation of the construction, operation costs, and its total costs presented in dimensionless form, the level of fencing thermal protection. By this procedure, you can select the most energy-efficient materials, constructions and building in general [19]. Yezerskiy V.A., Monastyrev P.V., Klychnikov R.Y. in their works determined maximum lifetime of the building in which its Thermo will be breakeven [24].

Samarin O.D., using techniques developed by specialists, members of the NP "ABOK", considered the effectiveness of investments in energy saving measures. In his works, he determined the influence of climate change on payback of additional warming Non transparent walling [17]. The most consistent and reasonable approach was developed by Gagarin V.G. He proposed an 
improved mathematical model of payback conditions to increase the level of thermal protection that takes into account more and discounting saving operating costs. In his works, VG Gagarin compared the significance of interest rates, as well as heating degree-days period and the price of thermal energy in the cities of Russia and the EU and CIS countries [05].

\section{METHOD}

The primary research method was the technical examination of the building and of the systems of central heating and ventilation (with the evaluation of their condition). Based on the results of the above-mentioned examination, the elabora tion of the measures to improve energy efficiency was conducted [10].

The building selected for examination is the "Uchebny corpus" of St-Petersburg Polytechnic University. This administrative building is typical from both: construction and exploitation. That is why the conclusions made in this research can be applicable to most of framed administrative buildings of the above period. Having no restrictions on changing the initial appearance of the administrative buildings of that period gives a variety of opportunities for technical solutions from both: construction and design.

The results of building survey:

- overall height of the building - 24,8 m;

- heated area - $11180.79 \mathrm{~m}^{2}$;

- heated volume - 43,605.08 $\mathrm{m}^{3}$;

- total area of the exterior walls $-14,155.57 \mathrm{~m}^{2}$. The survey of enclosing parts of building (Figure 1) [11]:
- total height of the building

$24,8 \mathrm{~m}$

- heated area $11180 \mathrm{~m}^{2}$

- building volume $43605 \mathrm{~m}^{3}$

- total area of exterior walls

The exterior walls of the building have the following structure:

- interior gypsum plaster $\quad 5 \mathrm{~mm}$

- brickwork of solid clay bricks on cement-sand grout $510-640 \mathrm{~mm}$

- cement-sand grout

$20 \mathrm{~mm}$

- stoneware tile

$10 \mathrm{~mm}$

Filling of the window opening - double glazing (with wooden or metal separate window casement). Glazing factor - 0,29.

Prefabricated concrete roof with cool attic.

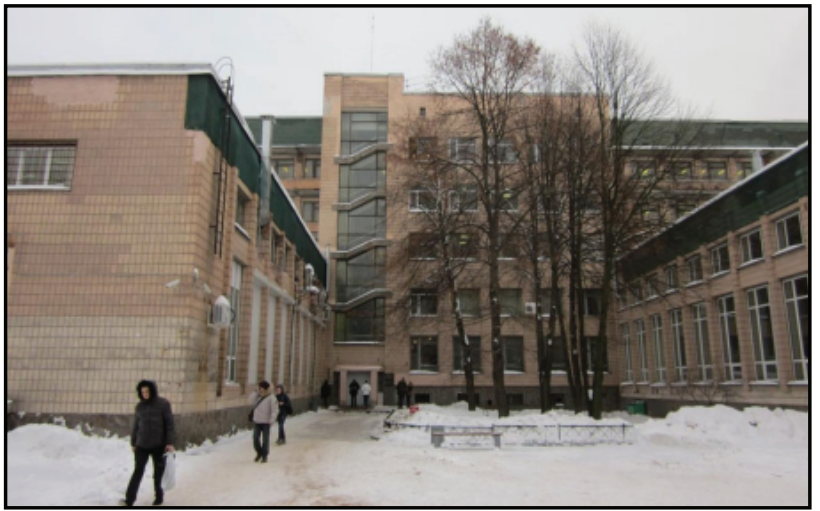

Figure 1: Appearance of the building

\section{Examination of the ventilation system of the building}

The complex examination of the system of mechanical ventilation of the building was carried out (Figure 2).

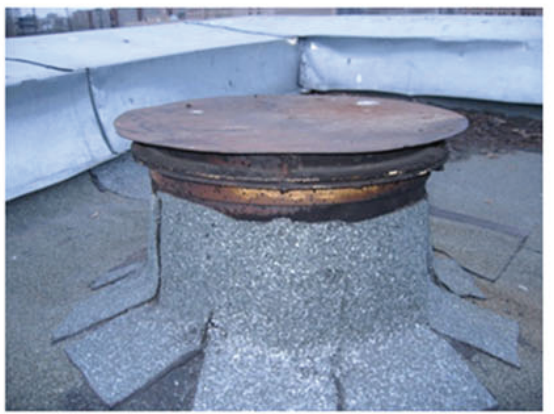

a)

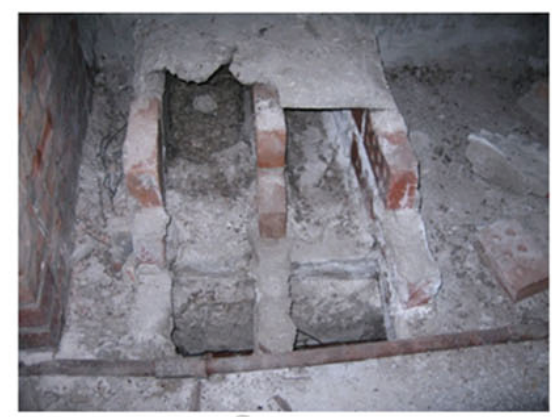

b)

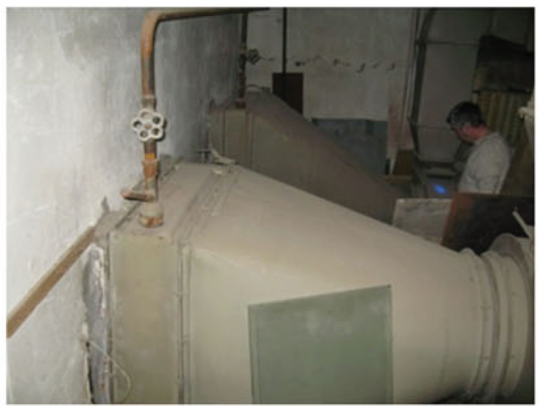

c)

Figure 2: The survey results ventilation systems.

a) the basis for the placement of the air-ejector roof ventilator; b) destroyed ventilation airways on the roof of the building; c) blowing ventilation systems in the "construction" performance) 
The examination revealed the following:

- the technical equipment of the ventilation system are situated on the roof of the building; the air-ejector ventilators are partly dismantled; the air-ejector airways are destroyed; systems do not operate;

- the technical equipment of the draw-in ventilation is placed in the inflow chamber, which is situated in basement; the mechanisms consist of separate elements and do not operate; the air-heaters are assembled with the violations of technical standards; systems and mechanisms are based on direct-flow principal; the systems of automatic regulation of heat consumption are not installed.

Thus it is obvious that the systems of mechanical ventilation are technically obsolete and must be replaced.

\section{Examination of the central heating system of the building}

The system of central heating has the following characteristics:
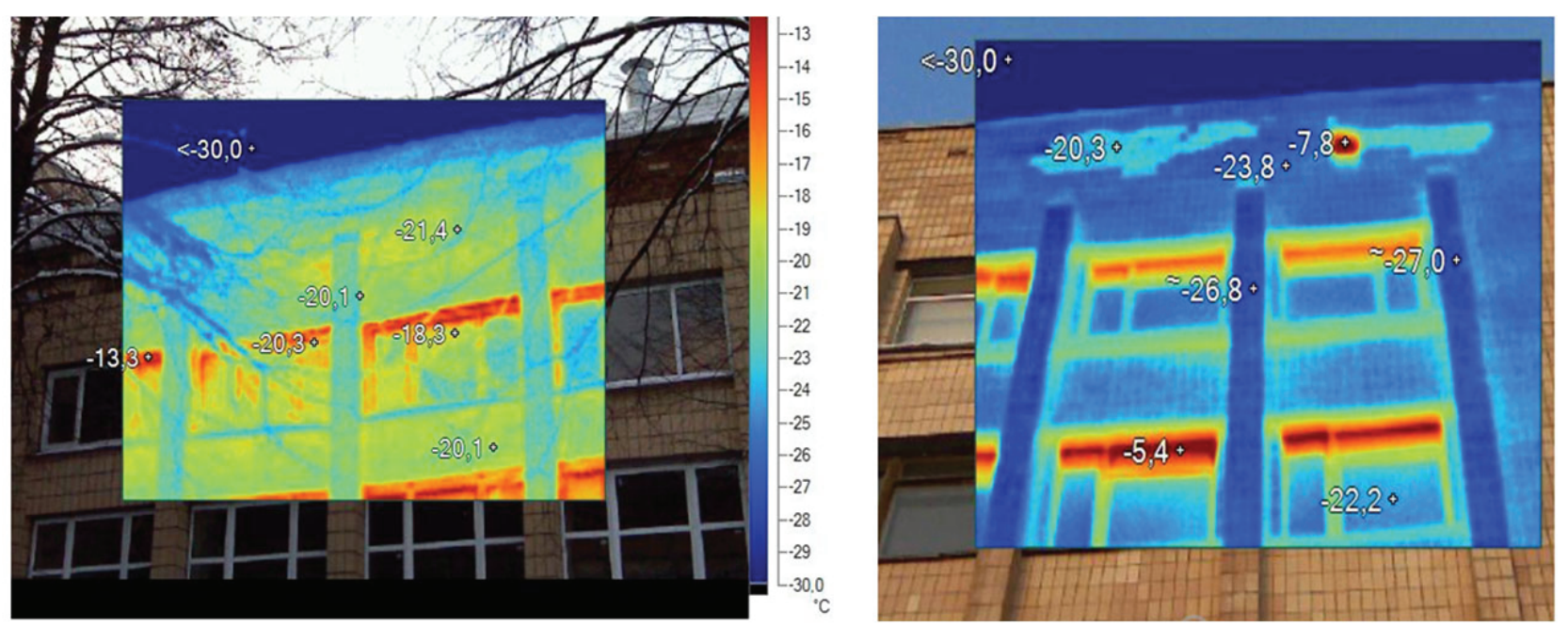

Figure 3: Thermogram obtained by thermal imaging inspection of exterior walls and skylights.

\section{RESULTS AND DISCUSSION}

Required heat transmission resistance exterior structure for public educational institutions:

- for the exterior walls - $R_{w}=2,433 \frac{\mathrm{m}^{2 . \circ} \mathrm{C}}{\mathrm{W}}$

- for coverings - $R_{C}=3,244 \frac{\mathrm{m}^{2.0} \mathrm{C}}{\mathrm{W}}$;

- for windows - $R_{F}=0,406 \frac{\mathrm{m}^{2} \cdot{ }^{\circ} \mathrm{C}}{\mathrm{W}}$.

Calculated (design) value of heat transmission resistance of external envelop :

- extemal wall-Rw=0,656 $\left(\mathrm{m}^{2} \circ^{\circ} \mathrm{C}\right) \mathrm{W}<2,433\left(\mathrm{~m}^{2 \cdot{ }^{\circ} \mathrm{C}}\right) \mathrm{W}$;

- coverage - Rc $=0,88\left(\mathrm{~m}^{2 \circ}{ }^{\circ} \mathrm{C}\right) \mathrm{N}<3,244\left(\mathrm{~m}^{2}{ }^{\circ} \mathrm{C}\right) \mathrm{N}$.
1. one-pipe dead-end system;

2. the system of automatic regulation of central heating equipment is default;

3. the system of automatic thermal regulation

is missing.

The heating system, draw-in and exhaust systems of ventilation of the building are obsolete and need to be replaced according to the modern standards of energy consumption [17].

\section{Resumes after shoot by thermal imagery device}

Thermal imaging is characterized by high selfdescriptiveness. The analysis of thermograms revealed the building sections with the highest heat losses. The spent shooting by thermal imagery device has revealed defects of windows, doors and external envelops. To standard requirements there correspond only windows in plastic double-glazed windows. Consequently, it is clear that there is a need for the replacement of filling of the window opening and for winterizing the outer walls of the building (Figure 3).

Windows for double glazing with separate metal casements:

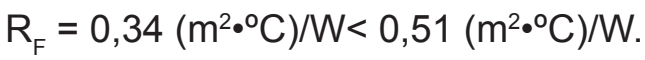

Windowsfor double glazing with separate wooden casements: $R_{F}=0,42\left(m^{2 \cdot{ }^{\circ}} \mathrm{C}\right) / \mathrm{W}>0,406$ $\left(\mathrm{m}^{2} \cdot{ }^{\circ} \mathrm{C}\right) / \mathrm{W}[20]$.

Filling of window openings should be replaced in order to reach the required value of reduced total thermal resistance [19]. 
The measures for the reduction of the heat losses of the building

In order to reduce heat losses through the outer walls and central heating system three variants of winterizing are considered (Table 1):

1) a Rainscreen cladding;

2) a facade covered with a thin layer of plaster;

3) a facade covered with a thick layer of plaster.

Table 1: Variant of the exterior walls construction

\begin{tabular}{|c|c|c|}
\hline Variant of construction & Scheme & Structure \\
\hline Rainscreencladding & & $\begin{array}{l}\text { 1. insulated walls; } \\
\text { 2. brackets; } \\
\text { 3. vertical guides; } \\
\text { 4. frontal expansion anchor } \\
\text { stud; } \\
\text { 5. insulation; } \\
\text { 6. ventilated air gap }(40-60 \mathrm{~mm}) \text {; } \\
\text { 7. cladding panel }\end{array}$ \\
\hline $\begin{array}{c}\text { Facade covered with a thin layer } \\
\text { of plaster }\end{array}$ & & $\begin{array}{l}\text { 1. special adhesive mixture; } \\
\text { 2. insulating panels of rock wool; } \\
\text { 3. frontal expansion anchor } \\
\text { stud; } \\
\text { 4. reinforcing filler; } \\
\text { 5. exterior glass cloth grid; } \\
\text { 6. water-dispersion primer; } \\
\text { 7. decorative mineral plaster; } \\
\text { 8. frontal silicone paint; } \\
\text { 9. ground profile; } \\
\text { 10. mating element; } \\
\text { 11. ground anchor; } \\
\text { 12. roughness compensator }\end{array}$ \\
\hline $\begin{array}{c}\text { Façade covered with a thick layer } \\
\text { of plaster }\end{array}$ & & $\begin{array}{l}\text { 1. fixing system consists of three } \\
\text { parts: anchoring part, } \\
\text { movable hook and three } \\
\text { clamping plate; } \\
\text { 2. insulating panels of rock wool; } \\
\text { 3. plaster mesh; } \\
\text { 4. soil and leveling mortar; } \\
\text { 5. lime-cement facade plaster; } \\
\text { 6. cladding structure }\end{array}$ \\
\hline
\end{tabular}

The thickness of an insulating layer and estimations of the payback period of the reconstruction were calculated for the thermal resistance of external walls that amounts to $2,433\left(\mathrm{~m}^{2.0} \mathrm{C}\right) / \mathrm{W}$ :

$\mathrm{R}_{\text {insulation }}=1,777\left(\mathrm{~m}^{2} \cdot \mathrm{C}\right) / \mathrm{W}$;

$\mathrm{d}_{\text {insulation }} \approx 125 \mathrm{~mm}$. [04].

The preliminary analysis of the technical and economic characteristics of the measures to winterize the building envelope demonstrated that the payback period can be considered as the basic index [12].

Payback period can be calculated as follows:

$T=\frac{K_{2}}{E_{2}-E_{1}}=\frac{\Delta K}{\Delta E}$, year where - $K_{2}, \Delta K$ - cost of expenses for work on warming of $1 \mathrm{~m}^{2}$ of the exterior wall, rub; [22]

$\Delta E$ - the difference between the heat losses cost through $1 \mathrm{~m}^{2}$ of the exterior wall $1 \mathrm{~m}^{2}$ to events on wall insulation $E_{1}$ and after warming $E_{2}$,rub/ year;

$\Delta E=\Delta Q \cdot C_{h}$ rub/year,

$\Delta Q$ - difference thermal energy loss per heating period, Gcal/year;

$C_{h}$ - cost of thermal energy for consumers (heat tariff). For Saint Petersburg in 2013 $C_{h}=1702,45 \mathrm{rub} / \mathrm{Gcal}$ including VAT; [21]

$\Delta Q=\frac{\Delta U \cdot D_{d} \cdot 24}{1000 \cdot 1163} \mathrm{Gcal} / \mathrm{year}$ 
$\Delta U$ - difference coefficients of heat transmission, $\mathrm{W} /\left(\mathrm{m}^{2} \cdot{ }^{\circ} \mathrm{C}\right)$;

$$
\begin{aligned}
& \Delta U=U_{1}-U_{2}, \mathrm{~W} /\left(\mathrm{m}^{2} \bullet{ }^{\circ} \mathrm{C}\right. \\
& U=1 / R, \mathrm{~W} /\left(\mathrm{m}^{2} \cdot{ }^{\circ} \mathrm{C}\right.
\end{aligned}
$$

$D_{d}$ - degree-days on the heating period. It has already been calculated value $D_{d}$ for St. Petersburg equal to $4110,9^{\circ} \mathrm{C} \cdot$ day/year;

24 - number of hours per day;

$1000 \cdot 1163$ - coefficient for transfer of power of heat flow from watts to Gcal [14].

Calculations of the thickness of the insulation layer and the payback period is defined for warming the variants. The first and the second variants of winterizing do not differ from the point of their payback periods. The payback periods are cal- culated according to the method [17] which do not take account of the following variables:

- rise of the tariff on the central heating;

- interest rates (in case a bank loan is a source of financing);

- rates of discounting;

- inflation rates [22]

This is the reason why the numbers describing payback period should be considered as a rough estimate.

The payback periods for the presented variants do not differ substantially. Functional relationship of the payback period and the heat transmission resistance of an external wall (for the $2 \mathrm{~d}$ variant of winterization) is indicated on the Figure 4.

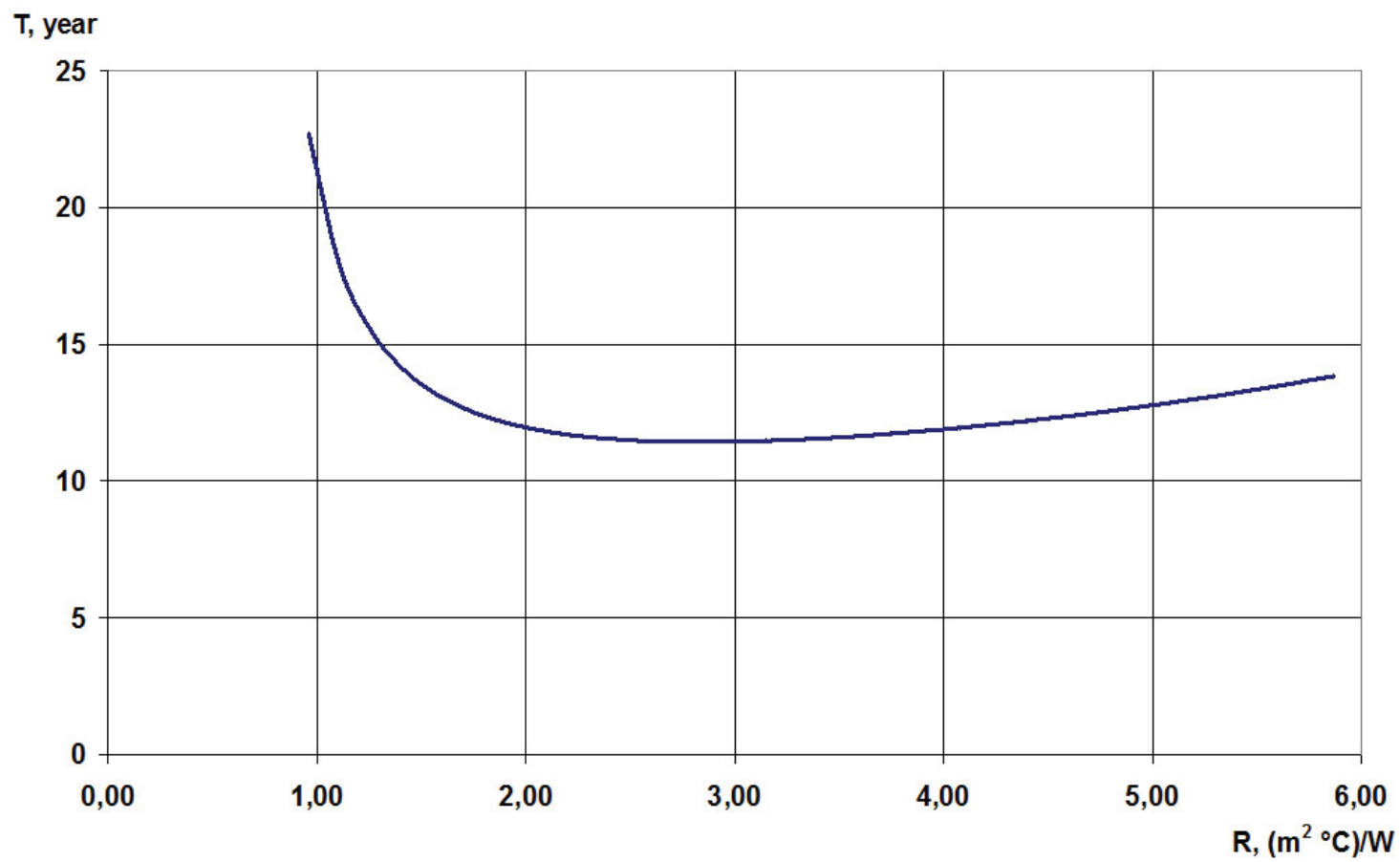

Figure 4: Dependence of the payback period on the reduced thermal resistance of external wall insulation for the second option

The optimal choice is the winterization construction (the thickness of heat insulation - 150 millimeters) that has the following characteristics:

- reduced total thermal resistance $-\mathrm{R}=2,77\left(\mathrm{~m}^{2} \cdot \mathrm{C}\right) / \mathrm{W}$;

- the payback period of the winterization $-T=11,4$ years [24].

Project of the reconstruction of the building with winterizing the external walls with the use of hinged vented façades (Figure 5).

\section{CONCLUSION}

- External envelops of 5-store building social educational services is not answerable to standard requirements.

- Value of defection calculate specific drain of energy on heating of building from standart requirements is $-9 \%$. So, it is a building of $E$ class («Very low») on energy efficiency. Necessary such measures on hight of class of energy efficiencyas:

1) Modernization and automatization of ventilation system, heater system; 
2) Exchange of windows;

3) Rise of thermal properties of external envelops;

4) The elaboration of the measures to improve energy efficiency should be based on the results of technical examination and economic calculations. In the research it is presumed that the basic indicator is the payback period of winterization. Decisions on financing measure that directed at the improvement of the energy efficiency shall be made only following the detailed analysis;
5) The optimal variant of the heat insulation of the external walls that is appropriate for this type of the buildings;

6) The examined administrative building is typical from point of its construction and maintenance regime. Therefore, the conclusion of this research can be considered applicable to the majority of frame modeled administrative buildings (constructed during the considered period).

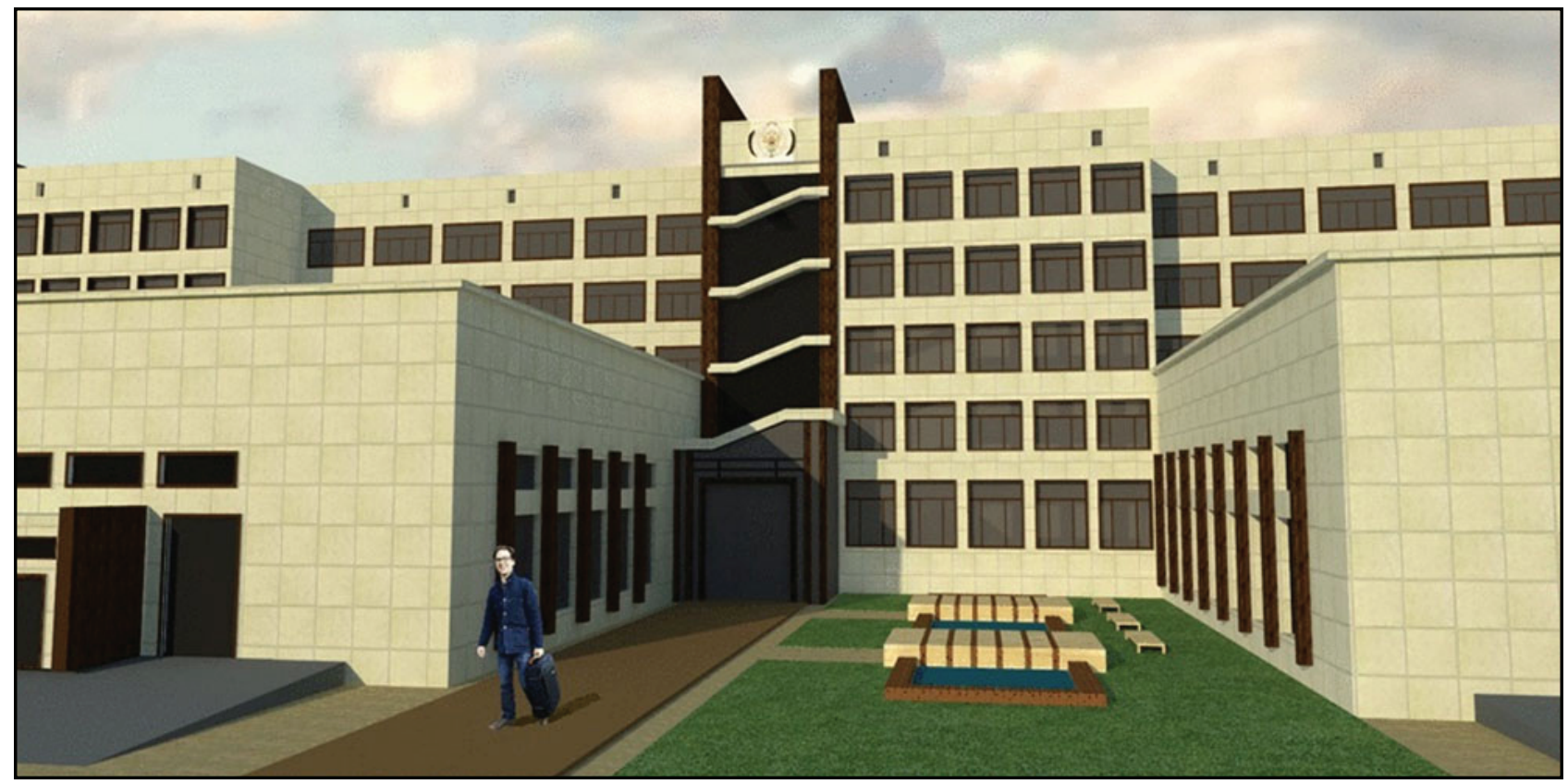

Figure 5: Reconstruction project

\section{REFERENCES}

1) Buildings and Climate Change Status, Challenges and Opportunities. Cited 109 times. United Nations Environment Programme Paris, (2007)

2) Boguslavskiy L.D., (1997), Ekonomiya teploty $v$ zhilykh zdaniyakh, Stroyizdat, 2-e izdaniye,11-119.

3) Casals, X.G., (2006), Analysis of building energy regulation and certification in Europe: Their role, limitations and differences, Energy and Buildings, 38 (5), 381-392.

4) Cvetkovska, M., Knezevic, M., Rogac, M., (2012), Thermal insulation effects on energy efficiency of building structures, Civil and Environmental Engineering UGM, No. XXI/2, Vol. 5, 1209-1215.

5) Gagarin V.G., (2009), Metody ekonomicheskogo analiza povysheniya urovnya teplo- zashchity ograzhdayushchikh konstruktsiy zdaniya, AVOK, 1, 10-18.

6) Directive 2002/91/EC of the European Parliament and of the Council of 16 December 2002 on the energy performance of building, Official Journal of the European Communities, (2009)

7) Dodoo, A., Gustavsson, L., Sathre, R., (2011), Building energy-efficiency standards in a life cycle primary energy perspective, Energy and Buildings, 43 (7), 1589-1597.

8) Escrivá-Escrivá, G., Álvarez-Bel, C., Peñalvo-López, E., (2011), New indices to assess building energy efficiency at the use stage, Energy and Buildings, 43 (2-3), 476-484.

9) Escrivá-Escrivá, G., (2011), Basic actions to improve energy efficiency in commercial buildings in operation, Energy and Buildings, 43 (11), 3106-3111. 
10) Jovanović, B., Božanić, V., (2013), Education in the field of energy efficiency in Serbia - Survey results and analysis, Journal of Applied Engineering Science, 11 (1), 15-22.

11) Matrosov, Y.A., Chao, M., Goldstein, D.B., (2000), Development, review, and implementation of building energy codes in Russia: History, process, and stakeholder roles, Proceedings ACEEE Summer Study on Energy Efficiency in Buildings, 9, 9.275-9.286.

12) Matrosov, Yu.A.,Norford, L.K., Opitz, M.W., Butovsky, I.N.,(1997), Standards for heating energy use in Russian buildings: A review and a report of recent progress, Energy and Buildings, 25 (3), 207-222.

13) Murgul, V., (2012), Povysheniye energoeffektivnosti rekonstruiruyemykh zhilykh zdaniy istoricheskoy zastroyki Sankt-Peterburga, Arkhitekton: izvestiya vuzov, 4 (40), 54-62.

14) Nemova, D.V., Tarasova, D.S., Staritsyna, A.A., Nefedova A.V., (2013), Results of educational building's inspection, Construction of Unique Buildings and Structures, 8 (13), 1-11.

15) Ramesh, T., Prakash, R., Shukla, K.K., (2010), Life cycle energy analysis of buildings: An overview, Energy and Buildings, 42 (10), 1592-1600.

16) Sartori, I., Hestnes, A.G., (2007), Energy use in the life cycle of conventional and low-energy buildings: A review paper, Energy and Buildings, 39 (3), 249-257.

17) Samarin O.D., (2010), Vliyaniye oriyentatsii osteklennykh fasadov na summarnoye energopotrebleniye zhilykh zdaniy, Magazine of Civil Engineerin, 8(18), 16-20.

18) Samardzioska, T., Cvetkovska, M., Lazarevska, M., Gavriloska, A.T, (2012), Imple- mentation of energy efficient measures in apartments in Macedonia, Life-Cycle and Sustainability of Civil Infrastructure Systems - Proceedings of the 3rd International Symposium on Life-Cycle Civil Engineering, IALCCE 2012, 1702 - 1708.

19) Savin V.K., (2010), Metody opredeleniya energoeffektivnosti okon i naruzhnykh ograzhdeniy pri ekspluatatsii zdaniy, Windows\&Doors, 3 (147), 22-23.

20) Thermal Performance of the Buildings. SNiP 23-02-2003. The State Construction Committee of the Russian Federation, The Central Institute for Type Designing Moscow.

21) Thermal Performance of the Buildings. Updated Version of SNiP 23-02-2003. SP 50.13330.2012 The Federal Center for Regulations, Standardization, and Technical Assessment of Conformity with Standards in the Construction Industry Moscow.

22) Vatin, N.I., Gorshkov, A.S., Nemova D.V., (2013), Energy efficiency of envelopes at major repairs, Construction of Unique Buildings and Structures, 3 (8), 6-11.

23) Vatin N.I., Nemova D.V., Rymkevich P.P., Gorshkov A.S., ( 2012), Vliyaniye urovnya teplovoy zashchity ograzhdayushchikh konstruktsiy na velichinu poter teplovoy energii v zdanii, Inzhenerno-stroitelnyy zhurnal, 8 (34), 4-14.

24) Yezerskiy V.A., Monastyrev P.V., Klychnikov R.Yu., (2011), Tekhniko-ekonomicheskaya otsenka termomodernizatsii zhilykh zdaniy. ASV, 112-176.

Paper sent to revision: 07.02.2014.

Paper ready for publication: 15.03.2014. 